\title{
THE ALLIANCE BETWEEN LAND AND CAPITAL DURING THE BRAZILIAN DICTATORSHIP
}

\author{
PRIETO, Gustavo Francisco Teixeira ${ }^{\text {a }}$
}

(a) Phd in Geography, University of Sao Paulo (USP). http://lattes.cnpq.br/2535677142724245

\section{(*) CORRESPONDING AUTHOR}

Address: Universidade de São Paulo, Avenida Prof. Lineu Prestes, 338, CEP: 05508080, São Paulo (SP), Brasil. Tel: (+55 11) 30913769 E-mail: gustavoteixeiraprieto@gmail.com

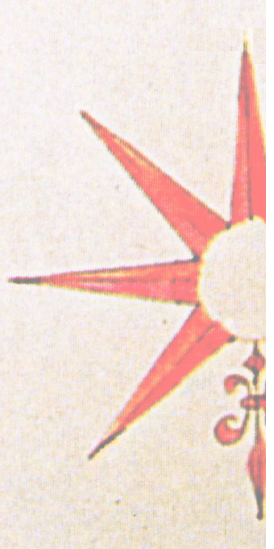

\begin{abstract}
This article aims to understand the economic, political and territorial foundation of the alliance between land and capital in Brazil from the imposition of the civil-military dictatorship (1964-1985), to reveal our understanding from three interrelated processes: the ideological arrangement that brought about the military coup, the production of the Land Act - promulgated on November 30, 1964 as a rural development project and not agrarian reform - and the land grabbing institutionalized by the authoritarian State over its 21 years. This alliance established a territorial pact that modernized the national State and placed the elites in power, namely the urban-industrial bourgeoisie and the large landowners. The text seeks to return to history to verify the mechanisms that established the alliance between land and capital from the analysis of legislation and the legal framework, official speeches and a literature review of / about the authoritarian State in order to understand the historical background of the Brazilian agrarian issue.
\end{abstract}

Keywords: Brazilian dictatorship (1964-1985), Agrarian question; Public land fraud.

\section{RESUMO/ RESUME}

\section{A ALIANÇA ENTRE TERRA E CAPITAL NA DITADURA BRASILEIRA}

O presente artigo tem como objetivo compreender os fundamentos econômicos, políticos e territoriais da aliança entre terra e capital no Brasil a partir da instituição da ditadura civil-militar (1964-1985), que se revela em nosso entendimento a partir de três processos interligados: o arranjo ideológico que instaurou o golpe militar, a produção do Estatuto da Terra - promulgado em 30 de novembro de 1964 como um projeto de desenvolvimento rural e não de reforma agrária - e a grilagem institucionalizada pelo Estado autoritário ao longo de seus 21 anos. Tal aliança instituiu um pacto territorial que modernizou o Estado nacional e reproduziu no poder as elites, quais sejam a burguesia urbana-industrial e os grandes proprietários de terra. $\mathrm{O}$ texto busca um retorno à história para verificar os mecanismos que instituíram a aliança entre terra $\mathrm{e}$ capital a partir da análise de legislações e arcabouço jurídico, discursos oficiais e revisão bibliográfica no/sobre o Estado autoritário a fim de entender os fundamentos históricos da questão agrária brasileira.

Palavras-chave: Ditadura brasileira (1964-1985); Questão agrária; Grilagem de terra.

\section{L'ALLIANCE ENTRE LA TERRE ET LE CAPITAL DANS LA DICTATURE BRÉSILIENNE}

Cet article vise à comprendre les facteurs économiques, politiques et territoriales fondamentaux de l'alliance entre la terre et le capital au Brésil auprès de l'institution de la dictature civil-militaire (1964-1985), qui se révèle, dans notre compréhension, a partir de trois processus interconnectés: l'arrangement idéologique qui a établi le coup d'Etat militaire, la production du Estatuto da Terra - promulguée le 30 Novembre 1964 comme un projet de développement rural et pas comme la réforme agraire - et l'appropriation privé des terres institutionnalisé par l'Etat autoritaire sur ses 21 ans. Une telle alliance a établi un pacte territorial qui a modernisé l'Etat national et reproduit dans les élites au pouvoir, à savoir la bourgeoisie urbaine et industrielle et les grands propriétaires terriens. Le texte vise un retour à l'histoire afin de vérifier les mécanismes qui ont établi l'alliance entre la terre et le capital en partant de l'analyse de la législation et du cadre juridique, des discours officiels et du revue de la littérature sur l'État autoritaire afin de comprendre le contexte historique de la question agraire brésilienne.

Mots cles: Dictature brésilienne (1964-1985); Question agraire; Accaparement des terres. 


\section{INTRODUCTION}

From the 1930s the industrialization process in Brazil acquired an effective economic impetus. More than the industrial spasms in previous years, the State apparatus headed by Getúlio Vargas developed effective policies for this sector's growth. During the 1940s and especially since 1950 there was an overwhelming peripheral industrialization (urbanization) process in Brazil, concentrated mainly in São Paulo and Rio de Janeiro. The urban-industrial bourgeoisie appeared to emerge as the social class that would occupy the political and economic forefront of national capitalist development, relegating the landowning class to a peripheral role in the distribution of the most valued global asset and simultaneously a decrease in their broad historical primacy in the political, ideological and legal determinations of the State. An honest mistake. The large landowners were not banned, in whole or in part, from economic, political and territorial class domination in Brazil, as happened in the development of capitalism in the central countries, such as in much of Western Europe, USA and Japan, as shown in the work of Wood (2009); Post (2009) and Kawano (1962) respectively. Exactly the opposite occurred: the large landowners actively participated as agricultural export agents sufficiently capitalized to integrate into the urban-industrial production system. Paulino and Almeida (2010) argue that only an occasional change of roles occurred because the oligarchies continued to maintain their sizable political and economic power by maintaining a concentrated land ownership structure, an effective form of access to income from the land and the modus operandi to play their central role in decision making within the State apparatus, allied to the nascent Brazilian industrial capitalists.

Paulino and Almeida (2010) emphasize that when conducting land reforms and / or land distribution processes the countries of central capitalism amplified the holders of the land. Thus, the power of the landowning class decreased in the definition of the parameters of the economic return of capital and the productive use of land in rural and urban areas was promoted. Indeed, this capitalist rationality suited the demands of expansion for the consolidation of the internal market and the development of the prevalence of profit at the expense of income.

Unlike the central capitalist countries, in Brazil there were no significant conflicts between landowners and the bourgeoisie, as the bourgeoisie emerged from the breast of the large estates (MARTINS, 1994; OLIVEIRA, 2007). What happened in the country was an alliance of class interests between land and capital producing a territorial, oligarchical and industrial pact (GARCIA JR, 1993; PAULINO; ALMEIDA, 2010) as a means, condition and product of the maintenance of the elites in power centered on the large agrarian properties. It is emphasized that the latifundium cannot be understood as a hindrance, an obstacle, a block or restraint to the expansion of capitalist relations of production in the countryside, as argued critically by Oliveira (2010), but instead as a fundamental contradiction of the capitalist mode of production and its forms of power and control of the economy, society and politics. Capital expands capitalist production in the countryside but also generates the latifundium and the reproduction of the peasants. This development logic is explained by a characteristic of the development of capitalism in Brazil: the predominance of latifundia was not an obstacle to capitalist reproduction (OLIVEIRA, 2010) but the possibility, through speculation, of producing capital outside the productive circuits, peremptorily demonstrating its rentier aspect.

Once the civil-military dictatorship in Brazil was established in 1964, there was a political rearrangement of the class fractions that dominated the State apparatus. However, this rearrangement produced a new convergence of political, economic and social interests between the industrial-urban bourgeoisie and the large landowners in a profound association with the authoritarian State headed by the military. The territorial pact that modernized the national State putting the economic elite in power was founded once more. The defense of the capitalist ownership of private land and land grabbing were at the center of this territorial strategy. In this sense, the objective of this article is to investigate the economic, political and territorial foundations of the alliance between land and 
capital in Brazil from the institution of the military coup, revealing our understanding through three articulated processes: the ideological arrangement that established the military coup, the creation of the Land Statute (enacted on November 30, 1964 by Law no. 4504) as a rural development project and not agrarian reform and land grabbing institutionalized by the authoritarian State throughout its twenty-one years.

\section{FROM THE “DANGERS OF LAND REFORM” TO ITS AUTHORITARIAN INSTITUTIONALIZATION}

Dreifuss (1981) and Martins (1994) emphasize that the 1964 State coup would not have been possible without the ideological intervention of the large landowners. Spread throughout the country, the large landowners acted as catalysts of the process of agglutination of class interests, gathering around themselves the urban bourgeoisie (business and industrial), segments of the middle class, part of the military and repressive apparatus of the State (mainly the armed forces) and conservative clerical groups in a trenchant criticism of the basic reforms of President João Goulart's government and the alleged (moral and ideological) "attacks" posed by the communists, trade unions and peasant movements to "tradition values": God, family and private property.

Martins (1994) considers that this arrangement is the ideological inversion of the liberal expression that associates freedom and equality, revealing that in Brazil the discourse of the oligarchy is based on the "freedom to be unequal." So, what was at stake in 1964 was the path that the capitalist modernization process would take in Brazil and in this way the landowners stood out for their protagonism in the reproduction of their class condition and their active and effective participation in the political arrangement of class fractions that would drive the authoritarian state.

There were certainly concerns about Goulart's discourse proposing basic reforms and the fear of the Brazilian elites and the United States regarding a possible communist mobilization carried out by peasant movements in Brazil (and in the whole of Latin America), especially after the 1959 Cuban Revolution. Martins (1994) and Ribeiro (2010) state that from the 1950s, the peasant struggle around the agrarian reform agenda and the transformation of the concentrated landownership structure vividly troubled the large landowners, in full association with the military. This is illustrated by the clashes between peasants and landowners in Porecatu (1950-1951) and Francisco Beltrão (1957) in Paraná; in Santa Fé do Sul in São Paulo (1959-1960); Engenho da Galileia in Vitória de Santo Antão - Pernambuco (1955) and the conflicts in Trombas and Formoso, in the north of Goiás between 1955 and 1956, in which the military acted brutally in order to suppress the agrarian mobilizations. According to Ribeiro (2010), the strong presence, real or imagined, of the Communist Party in the Brazilian countryside and the mobilization of the peasant class and the rural trade unions, from the point of view of many military leaders transformed the agrarian question into a problem to be solved. This equation was certainly the reverse of the radical reform proposals of the Peasant Leagues and the Communist Party.

Silva (2006) argues that during the 1950s and 1960s there was a broad agglutination of class politics with a cohesion rarely seen in Brazilian history, a cohesion that mobilized to maintain the interests of national and multinational urban-industrial capitalists and the agrarian oligarchs. This capitalist juncture materialized in various organizations, such as the Brazilian Institute for Democratic Action (IBAD), which advocated an industrialization path that articulated the national bourgeoisie with multinational interests more forcefully, that guaranteed US interests in the Brazilian economy and mounted a strong opposition to national-development groups, trade unionists and Communists (SILVA, 2006). The IBAD was directly associated with the National War College (ESG) and the National Council of Producers (CONCLAP), created in 1955. In São Paulo, the industrial bourgeoisie coalesced around the Federation of Industries of the State of São Paulo (FIESP), which held the 
presidency of CONCLAP. In turn, CONCLAP was associated with the landowners organized into the Brazilian Rural Society (SRB), which had significant political force. For example, it is noteworthy that in São Paulo the SRB was one of the main proponents of the March of the Family with God for Freedom in March 1964, as argued by Martins (1994). This march occurred at the local level and encouraged landowning leaders in various regions of Brazil to spread the capitalist ideology of private property and political conservatism, and oppose social reform and Communism. The capillarity of the large landlords served as a central point to support the ideological dissemination of the "dangers" posed by land reform to Brazilian (economic, social and political) development.

The group of opponents of the Goulart government also included the Institute for Research and Social Studies (IPES). Founded on February 21962 in Rio de Janeiro, IPES was the product of the articulation between the business communities in Rio de Janeiro and São Paulo. The institution steadily agglutinated the capitalist classes from other states. The intensification of the debates on basic reforms, especially in 1963 and 1964, encouraged the members of the IPES in their perception that the country was marching inexorably toward Communism and that it was up to "good men" to interrupt this process (CAMARGO, 2007). The IPES was particularly concerned with forming public opinion and spreading an ideological anti-reform and anti-communist propaganda in the media (SILVA, 2006). Peremptorily focused on strategies, the IPES had key support from IBAD, which acted as tactical unit, accounting for covert activities (SILVA, 2006; DREIFUSS, 1981). The two complemented each other in their opposition to the so-called populism, the national-reformist Executive and popular social forces.

According to Oliveira (1997), IPES and IBAD were used extensively in the overthrow of the Goulart government by the social classes and parts of the armed forces favorable to the coup, in explicit association with the ESG. The ESG was formed in 1949 and relied on various bilateral military agreements between Brazil and the United States. Oliveira (1997) found that especially after the 1950s the Brazilian military was strongly associated with the urban-industrial bourgeoisie and landowners in an ideological coalescence to combat Communism, social mobilizations (especially in the countryside) and basic reforms. Simultaneously, they were interested in pursuing the proposed expansion of capitalist modernization processes brought about by the oligarchy and the urban-industrial bourgeoisie: politically centralized national development, a deepening ideological alignment with the United States, repression of the specter of Communism in Latin America, the internationalization of the economy, opening the market to multinational companies, agro-industrial expansion and the capitalist occupation of national borders.

Martins (1994) and Silva (2006) also emphasize that the IPES and IBAD were dedicated to the issue of land reform in order to carry out a distinctly different reform proposal to those defended by the Peasant Leagues or the agencies of the Goulart government. They articulated with the US political and economic program, known as the Alliance for Progress. The Alliance was officially established in 1961 as a form of financial support from the United States to development and economic progress in Latin America, but unofficially and covertly it was a policy to counter the "danger" of Communism being established (PEREIRA, 2005; RIBEIRO, 2006) and the reproduction of the Cuban revolutionary model that was widely supported by the peasant class. Silva (2006) argues that the land reform proposed by IPES and IBAD developed with the following objectives as guidelines: the project should be designed by "experts" based on "technical" criteria. Ideologically, the redaction should be drawn up by liberal political forces on the economic level, be pro-American in terms of foreign relations and "anti-populist" on the social and political level.

It is noteworthy that immediately after the civil-military coup the Working Group on the Land Statute (GRET) was established under the organization of the Ministry of Planning, and which had the objective of proposing a document that would serve as a basis for a draft bill on land reform and other constitutional amendments. According to Bruno (1995), the group was formed by the reformist wing of the IPES, coordinated by Paulo de Assis Ribeiro and by a few remnants of the 
Agrarian Revision of the Carvalho Pinto Government in São Paulo in 1959, in which José Gomes da Silva was a central figure. In addition, there were several technical and political representatives from various ministries, as well as the Planning Minister Roberto Campos and the Minister of Agriculture Oscar Thompson. Bruno (1995) points out that the GRET still had the direct supervision of General Golbery do Couto e Silva (head of the National Information Service) and the constant participation of Castello Branco.

In a speech on May 22, 1964 Castello Branco emphasized his interpretation of land reform and, above all, the role of the Land Statute, which according to the dictator-president, was

(...) the legal instrument for the effective implementation of land reform. A land reform that, free of demagogic radicalism, meets the real aspirations of rural workers as well as the increasing domestic production. That is, a set of measures which with the modification of the system of ownership and land use aims to increase the numbers of the rural middle class, which is to say, promoting social justice in the countryside. They are intended to increase the welfare of rural workers and their families, contributing at the same time to the country's economic development and the gradual extinction of long accumulated errors. (BRASIL, 1964f, p. 52-53)

Thus, according to Dreifuss (1981), the guidelines for the production of land reform legislation, which was accomplished with the creation of the Land Statute, were based on recommendations made by the IPES with the direct participation of Castello Branco. It is important to emphasize that the reordering of American foreign policy with the Alliance for Progress aimed to encourage Latin American countries to promote reforms in their agricultural structures. This change of direction was largely influenced by the Cuban Revolution and the fear of new revolutionary processes in Latin America (SILVA, 1997; RIBEIRO, 2006). According to Silva (1997) US diplomacy concluded that

the danger of new revolutions could be avoided if Latin American governments became aware of the need to change the situation of the peasant masses and that land reform was considered the key instrument to achieve this goal (SILVA, 1997, p. 20).

In this sense, Bruno (1995) argues that reforms, especially land reform, were treated by the Castello Branco government on the basis of a different social commitment, that is, in the way that dictatorships treat social issues. Reforms are disconnected from their social origins and re-signified as concessions of a "revolutionary" government. In this way, the Castello Branco government simultaneously repressed peasants and union leaders in the countryside and intervened in land disputes in favor of land grabbers and / or landowners, and moreover, sought to control what workers should discuss and demand. Bruno (1995) points out that in relation to João Goulart's proposed land reform "there was not only a retreat or a change in tone of the struggle for land reform, but also a change in content: it shifted from a frontal attack on latifundia to the defense of the Land Statute" (BRUNO, 1995, p. 12).

Immediately after the coup the dictatorship began the process of purges, expulsions and persecution of the political leaders identified with a more radical land reform program. On April 9, 1964 this process became even more evident with the promulgation of Institutional Act $n^{\circ} 1$ (AI-1). With this Act a significant part of the parliamentary opposition in the Brazilian National Congress was purged, with more than 40 members losing their mandate - among them Francisco Julião (PSB-PE), a leader and lawyer of the Peasant Leagues and Plinio de Arruda Sampaio (PDC-SP) the rapporteur of the Goulart Government's land reform project. Thus, Congress came to have a large majority of members from the parties affiliated with the UDN and the PSD, clearly identified with a vehement criticism of the land reform projects and struggles in the countryside.

It is important to note that the Land Statute and the legal proposition embodied in the civil-military dictatorship's land reform law was the strategy used by the authoritarian State to legally 
appease the peasant struggles. It was implemented primarily in regions with land conflicts and simultaneously assured landowners that the strict letter of the law would be produced, approved and discussed in Congress, but not implemented. Despite its content with new legal forms and the materialization of a progressive legal discourse, Oliveira (2007, p. 121) reminds us that "it was the actual Minister of Planning of the military government at the time, Roberto Campos, who guaranteed the landowning Congressman that the law was to be approved but not put into practice. "

Thus, Martins $(1980,1981)$ argues that the Land Statute was presented as a land reform law, but was in fact a legal framework that presupposed rural development based on the capitalist rationalization of agriculture for the purpose of modernization of the large estates and the transformation of smallholdings into capitalist enterprises.

It is noteworthy that at the start of the civil-military dictatorship it was instrumental that the form of developing and creating laws followed the same path of as the democratic period. However, it was more efficient, agile and had a higher quality, since the danger of the "Bolshevization" of Brazilian politics ${ }^{1}$ was removed and "demagogic radicalism" was separated from the production of the legal and policy frameworks for Brazilian (capitalist) modernization. In this sense, from Oliveira's analysis (2007) it is understood that the Land Statute spells out the contradiction between the land reform project and its non-implementation. So it carries within it the character of a historical farce based on the reification of capitalist private landownership, an institutionalized rhetoric of land reform that was based on the intent to demobilize and repress the peasantry and act in the broad defense of corporate agriculture in the form of the latifundium. Thus, the Land Statute acted as the legal framework of the reproduction of the class power of the landlords and as a reference for understanding the territorial pact maintaining the scorching Brazilian land concentration.

For example, one can observe the institutionalized rhetoric of land reform in the civil-military dictatorship's proposal (Message ${ }^{\circ} 33$ of October 26, 1964 forwarding to Congress the bill that deals with the Land Statute) as the "democratic solution" to stimulate private property. Under the terms of the dictatorial Message:

15. Based on these evils it is imperative to examine the solutions. Two options immediately present themselves to solve the problem: the socialist option and the democratic one.

The first is characterized by the following outline: a) it aims to transfer, immediately or gradually, land ownership to the State; b) it eliminates freedom of initiative, attributing to each rural worker the execution of predetermined tasks in accordance with a comprehensive State plan; c) it transforms workers into simple users of land that is owned collectively or by the State, removing the stimulus of the advantage of increased production.

16. The democratic option is based on the stimulus of private ownership, on the right of the agricultural owners to the fruits of their work and, naturally, on increased productivity. It reintegrates the property to its natural social function, conditioning its use to general welfare; based on the modular concept of the area of the rural establishment it creates a system that allows the formation of property, its economic size relative to the family unit. (BRASIL, 1964b, p. 121, emphasis added)

This "democratic option" of military land reform can be verified by the broad defense of private property in the Land Statute from different prisms. Together with the interpretation of Martins (1994) and Ribeiro (2010), we understand that despite the social content of the law based on a process of

\footnotetext{
1 In the Institutional Act $n^{\circ} 1$ of April 9, 1964 this conservative and authoritarian ideology is evident: “(...) the present institutional Act may only be edited by the victorious revolution, represented by the Commanders in Chief of the Armed Forces who are currently responsible for achieving the revolutionary objectives, whose frustration they are determined to prevent. Constitutional processes had not succeeded deposing the government, which deliberately intended to bolchevize the country. Deposed by the revolution, only they may dictate the norms and the processes of forming the new government and give it the powers or legal instruments to ensure the exercise of power in the exclusive interest of the country "(BRASIL, 1964e, p. 3257).
} 
agricultural modernization that binds land ownership and the enforcement of social function, there are a set of strategic gaps intended to prevent, hinder and obstruct land reform and therefore block the real possibilities of effecting a change in agrarian structure. Ribeiro (2010) emphasizes that there were a set of obscure and intentionally confusing definitions in the provisions of the Law. The author emphasizes the definition of latifundium:

Article 4 For the ends of this Law, the following are defined: (...)

V - "Latifundium", the rural property which: a) exceeds the maximum size set in accordance with article $46, \S 1$, paragraph b of this Law, taking into account the ecological conditions, regional farming systems and the purpose for which it is intended; ${ }^{2}$ b) Not exceeding the limit referred to in the previous paragraph, and having an area equal to or above the dimensions of the module of a rural property, be it unexploited in terms of its the physical, economic and social possibilities, for speculative purposes, or be it inadequately or poorly exploited, in order to prevent its inclusion in the concept of a rural enterprise; (BRASIL, 1964c, p. 127).

According to Carvalho Filho (1997) and Ribeiro (2010), the purpose of this obscurely drafted legal instrument, such as its broad formal subjectivism and legal vagueness was to hinder the expropriation of farms that apparently met the legal requirements in some of the terms listed.

The Land Statute used three definitions of property: smallholding, latifundium and rural enterprise. The rural enterprise was exempted from expropriation procedures, since under the Statute it indelibly complied with the social function of property, which would not be the case with the first two. Rural properties with an area smaller than the rural module were called smallholdings and should be consolidated because they were considered essentially uneconomic. However, large estates should be redistributed and could be classified as latifundium by exploitation or latifundium by size. The latifundium by exploitation corresponded to a property with an area between one and 600 rural modules that did not meet its social function. The latifundium by size was any property with an area greater than 600 rural modules, regardless of whether or not it met the other requirements of social function, since above this limit the property was considered an antisocial asset. This distinction apparently undoes the vagueness and conceptual obscurity. However, in practice the "military's land reform" (OLIVEIRA, 2007) would reiterate the maintenance of the latifundium. Martins (1981) points out that the Land Statute was much more incisive with smallholdings than latifundia, as smallholdings should consolidate and modernize, while latifundia, once transformed into rural enterprises, could maintain their territorial extension.

Moreover, by establishing land reform as rural development the civil-military dictatorship strongly supported the modernization process of large properties with tax incentives and bountiful credit. Furthermore, the definition of latifundia by size was practically abandoned as massive incentives for their transformation into rural enterprises were offered during the civil-military dictatorship through a set of programs designed to attract urban business groups to the countryside (OLIVEIRA, 2011). The realpolitik of the civil-military dictatorship was accomplished by a heavy drain on public resources for the reproduction of the latifundium.

The Brazilian dictatorship created the legal instruments to implement land reform and simultaneously institutionalized political and legal barriers to its effectiveness. Martins (1980), Marés (2003) and Oliveira (2007) found that the Land Statute maintained the full contractual legitimacy of private property because even when the social function of property was not fulfilled its legitimacy was not questioned.

2 Article 46, $\S 1$, paragraph b the Land Statute stipulates that "the maximum limits permitted to the areas of rural properties shall not exceed six hundred times the average module of the rural property or six hundred times the average area of rural properties in the area concerned" (BRASIL, 1964c, p. 132). 
The defense of private property can be observed in the relationship between Articles 12 and 15 of the Land Statute, in which at the same time that it states that private property should fulfill a social function, its use for land reform purposes would be given priority in areas with land conflicts:

Article 12. The private ownership of land is inherently a social function and its use is conditioned to the collective well being provided in the Federal Constitution and characterized in this Law. (...)

Article 15. The implementation of Land Reform on private land will be done on a prioritized basis, in the case of critical areas or social tension. (BRASIL, 1964c, p. 130)

In addition to this item in the Land Statute, Constitutional Amendment 10 of November 9, 1964 should be noted, which was approved twenty-one days before the general approval of the Statute and guaranteed private property and modified the form of compensation for expropriation, providing that

Article $4 \S 16$ of article 141 of the Federal Constitution shall read as follows: "§ 16 . The right to property is guaranteed except in the case of expropriation for public necessity or utility or social interest, subject to prior and fair compensation in money, with the exception provided for in $\S 1$ of article 147 . In the case of imminent danger, such as internecine war or commotion, the competent authorities may use private property, if required for the public good, provided however, that the right to further compensation is guaranteed"

Article 5 To article 147 of the Federal Constitution are added the following paragraphs: "§ 1 For the purposes foreseen in this Article the Union may promote the expropriation of rural property through the payment of prior and fair compensation in special government bonds, with an exact indexation clause according to rates set by the National Economic Council, redeemable within twenty years in successive annual installments. Their acceptance is ensured at any time as a means of payment of up to fifty percent of Rural Land Tax and as payment of the price of public lands. (...)

$\S 3$ The expropriation referred to in $\S 1$ is the exclusive competence of the Union and will be limited to areas in the priority zones established by decree by the Executive Branch, only affecting rural properties whose form of exploitation is contrary to the provisions of this article, as defined by law.

$\S 4$ The compensation in securities will only occur in the case of latifundium as conceptualized in law, except for the necessary and useful improvements that will always be paid in money. (BRASIL, 1964d, p. 34-35).

That is, private property was guaranteed but the form of compensation changed in the expropriation process. The Land Statute set out in Article 17 that land reform could occur by expropriation for social interest, donation, purchase and sale and inheritance or legacy. Expropriation for social interest to implement land reform was an instrument highlighted in Law 4.504. However, Martins (1981) points out that this instrument was mainly applied in areas of conflict (as explained in the aforementioned article 15 of the Land Statute and Article 5 of the Constitutional Amendment). It is fundamental to emphasize that one of the items that was vetoed considered one of the forms of land reform to be the "reversion of the possession of land owned by the Public Authorities, when wrongfully occupied and exploited in any way by third parties" (BRASIL, 1964c, p. 131). Reversion of possession is a legal concept that presupposes the recovery by the State of illegally appropriated assets. Obviously, this device breaks with individualistic ownership and the absolute liberal protection of property, that is, this means a lack of guarantee of the absolutism of the right to property and therefore does not fit the ideological assumptions of the bloc that dictatorially seized power.

Regarding expropriation, the Land Statute states in Article 18: 
Article 18 The expropriation for social interest aims to: : a) condition the use of land to its social function;: b) promote the fair and appropriate distribution of property; : c) require rational land use; : d) permit the social and economic recovery of regions; : e) encourage pioneering research, experimentation, demonstration and technical assistance; : f) carry out the renovation, improvement and enhancement of natural resources; : g) increase electrification and industrialization in rural areas; $: \mathrm{h}$ ) provide for the creation of protected areas for fauna, flora and other natural resources in order to preserve them from predatory activities. (BRASIL, 1964c, p. 131)

\section{It also presupposed that}

Article 1 The expropriation shall be conducted in the manner provided for in the Constitution, subject to the provisions contained in this Law.

$\S 2$ For the ends of expropriation the following principles shall be observed: a) to fix the just compensation, in the form of article 147, $\S 1$, of the Federal Constitution, the value of the property declared for the purposes of the Rural Land Tax shall take into account the value in the registration plus the improvements with possible monetary correction, calculated in the form of the specific legislation and the market value thereof; (...)

Article 31 The Brazilian Institute of Agrarian Reform is authorized to: (...) II - set the bonds of the National Agricultural Debt for the purposes of this Law; (BRASIL, 1964c, p 131 -. 135).

To implement expropriation procedures agrarian debt bonds, commonly known as TDA, would be used. The civil-military dictatorship, therefore, quickly removed the provisions of article 147 of the 1946 Constitution (as can be seen in Article 5 of the 1964 Constitutional Amendment effectuated by dictator-president Castello Branco), allowing expropriation for social interest, without prior compensation in cash but through government bonds. It is noted that within a few months and starting from the authoritarian State and a Congress dominated by representatives of the industrial-urban bourgeoisie and land oligarchies, one of the main legal fences for effective land reform between 1946 and 1964 was changed constitutionally. Two others were instituted: the first, the agrarian debt bonds and the consequent transformation of expropriation into a capitalist business, which were an important economic fence. The second, a key political fence that changed the law for the implementation of land reform, but which in fact established a rural development project aimed at the creation of large farms and based on extensive land grabbing (PRIETO, 2016). Now we will concentrate on the true legalization of illegal occupation due to the militarization of the agrarian question in Brazil between 1964 and 1985.

\section{THE LEGALIZED LAND GRABBING OF THE BRAZILIAN CIVIL-MILITARY DICTATORSHIP}

The land policy implemented during the dictatorship was characterized by the failure to carry out land reform making any possible progressive aspect of the Land Statute virtually meaningless. According to Carvalho Filho (1997), the first fifteen years of the duration of the Statute only benefited 9,327 families in land reform projects. However, the concentration of land ownership and inequality in the countryside grew sharply. According to Martins (1980) in 1975, 52\% of rural establishments had less than ten hectares and only covered $2.8 \%$ of the total area. An emblematic example of the colossal extent of the latifundia is the Jari Project, led by the American billionaire businessman Daniel K. Ludwig who came to own more than 4.6 million hectares on the border between Pará and Amapá. 
As a substitute for land reform the option was colonization projects, mainly on Brazil's northern border (the results were also modest: 39,948 families assisted according to CARVALHO FILHO, 1997) and the large rural development projects that received the bulk of dictatorial investments and incentives. In this sense, it is noteworthy that from the 1960s the frontier of capitalist expansion turned to the Brazilian Amazon and it is especially through the analysis of this region that one can verify how the maintenance of the concentration of land ownership occurred due to the legalized grabbing of public lands under the auspices of the authoritarian State.

It is therefore crucial to recall that between 1964 and 1970 the Brazilian Institute of Agrarian Reform (IBRA) - which was established by the land statute as the official body to implement agrarian reform in association with the National Institute of Agricultural Development (INDA) - developed an intense process of land grabbing and the sale of public lands to foreigners with the acquiescence of a number of civil servants and public notaries (FIGUEIRA, 2000; OLIVEIRA, 2011). According to Oliveira (2011) this process can be seen in the Parliamentary Inquiry Commission set up in 1968 to investigate the denouncement of the transfer of huge portions of the national territory to private ownership. According to Oliveira's analisis $(1997 ; 2009 ; 2011)$ of the Commission's final report, the rapporteur being the congressman Haroldo Veloso (ARENA-PA), the involvement of land grabbers, judges, employees of IBRA and public notary offices was verified in the sale of more than 20 million hectares of land to foreigners, especially in the Amazon, via a set of artificial arrangements to expedite land ownership, such as

Brazilians acting as middlemen, purchases with former owners or leaseholders, requisition of vacant land to the state governments and grabbing of public land. This tragedy in Brazilian history was part of the policy pursued by the military governments and national and international companies, aiming to exploit the country's natural resources. (OLIVEIRA, 2009, p. 16)

In addition, according to Oliveira $(2007 ; 2011)$ the civil-military dictatorship's strategy of illegal appropriation of public land was accomplished in various forms; one of the most invariable was trying to regularize land through middlemen using false powers of attorney. Thus, federal or state public land could be acquired through land grabbing, with areas larger than the Constitution allowed. The 1967 Constitution, produced during the dictatorial government, provided that

Article 164 Federal law shall provide for the legitimate conditions of ownership and preferably the acquisition of up to one hundred hectares of public land by those who make them productive with their work and their family's work.

Single paragraph Except for the implementation of land reform plans, the disposal or concession of public lands with an area over three thousand hectares will not be made without the prior approval of the Senate (BRASIL, 1967, p. 38).

In 1969 a constitutional amendment altered the 1967 Constitution but confirmed the limitation of ownership to a maximum of one hundred hectares and divestitures and concessions of up to three thousand hectares. However, this legal instrument did not prevent various practices of illegal occupation, such as:

the sale of the same land to various buyers; the resale of public land deeds to third parties as if they had been legally put on sale through bidding processes; the falsification and demarcation of the land purchased by someone with a much greater size than that which was originally acquired, with the proper documents extending it; the fabrication or tampering with property titles and various certificates; the incorporation of public land to private land; the sale of land titles allocated to areas that do not correspond to the property; the sale of public land, including indigenous and environmental conservation areas, by private agents to third parties; consolidation of the land on the sides of the major federal highways, 
which in previous years had been distributed in small lots to farmers for land reform and the subsequent sale of the subdivided lots, subsequently consolidated, turning them into large cattle ranches; and more recently, the sale of public land over the Internet as if the sellers were its rightful owners, based on forged documents. (LOUREIRO, PINTO, 2005, p. 79)

It appears that the Legal Amazon, which has 508.8 million hectares, has gone through a series of private appropriations of public land. The geopolitical strategy of occupation and exploitation of the Amazon was the agrarian conter-reform of the authoritarian State (IANNI, 1979), which named colonization projects in the Brazilian Amazon land reform (OLIVEIRA, 1997). These projects were carried out by INCRA, created by Decree-Law n ${ }^{\circ} 1.110$ of July 9,1970 . This decree extinguished the IBRA and INDA and transferred all the responsibilities of the former institutes to the new organization. In the same period the National Integration Programme (NIP) and the Land Redistribution Program (PROTERRA) were created. One can synthesize the ideological discourse of the programs with the following assertion: the occupation of the so-called demographic voids in the Amazon by the surplus Northeastern population in order to "integrate" the north of Brazil to the rest of the territory (embodied in the Medici government's slogan "land without men in the Amazon, for the northeastern men without land "). Moreover, there was an effort to produce "economic enclaves" in the Amazon and create official colonization along the Trans-Amazonian and Cuiabá-Santarém highway, as well as agricultural centers, such as the Polamazônia and part of Polocentro and Polonoroeste. Oliveira (1997) emphasizes that all the projects were financed by large banks and international financial bodies such as the Inter-American Development Bank (IDB) and the World Bank, among others.

Oliveira (1997, p. 89) argues that

PIN, INCRA and PROTERRA formed an articulated scheme behind the scenes of the military government. That is, General Medici's government created a program that simply contradicted the Land Statute which provided for expropriation through payment with "Agricultural Debt Bonds - TDA". But now, through PROTERRA, this expropriation was to be made through "prior and fair compensation in money (item "a" of Article 3). Another link in the "agrarian counter-reform" had been established, that is, "reform in favor of the large landowners."

The proposed internationalization of the Amazon was associated to the offer of a number of tax advantages to big business and national and international economic groups that wanted to invest new capital in the projects that would settle in the region (FIGUEIRA, 2000; LOUREIRO; PINTO, 2005; PINTO, 2014). It sought to incorporate the Legal Amazon in the process of capital production at the national and international scale, economically incorporating the region from the development of capitalist agricultural business. Such integration occurred through a vast policy of tax deductions, tax incentives and subsidized loans made by the civil-military dictatorship to industrialists and entrepreneurs who acquired land in the Amazon.

These incentives, offered since the dictatorial government of Castello Branco (and increased in the Geisel administration), were intended to promote livestock farming, logging and mining, activities that simultaneously require large amounts of land and exploit natural resources. Thus, from the Amazon Development Superintendence (SUDAM) and Banco da Amazônia, there was a policy of granting tax incentives to urban businesses so they would be exempt from paying 50\% of their income tax, provided that the money was deposited in that bank to finance development projects in the region, whose capital constituted up to $75 \%$. Investments for the development of capitalist agriculture in vast tracts of land were given priority so that a large number of entrepreneurs, industries and companies from the South and Southeast of Brazil became landowners and rural entrepreneurs. In addition, large national and multinational groups with few or no activities related to agriculture became landowners in the Brazilian Amazon, such as Volkswagen, Bradesco, Bamerindus, Supergasbrás, Atlantic Boa Vista and Manah, among others. 
Ianni (1979) emphasizes that land grabbing was not one among other forms of land acquisition. It was the most important because it was often associated with the purchase and sale of land, or better still, land grabbing systematically joined together with other land acquisition procedures, so that often it was impossible to distinguish between them. In this sense, Ianni $(1979$, p. 167) states that "counterfeiting and the veracity of documents and evidence and witnesses are merged" through the association between "land grabbers, entrepreneurs, lawyers, officials and others." When analyzing the INCRA register in 2003 Oliveira (2011) found that there were more than 67 million hectares of vacant land in the Amazon. However, despite being public and / or vacant land many of them are surrounded by the power of the land grabbers-owners who define the boundaries between legality and illegality not only in the Amazon or in the frontier areas of capitalist expansion but in the whole Brazilian territory. According to the Report of the Parliamentary Inquiry Commission that investigated the occupation of public lands in the Amazon (the CPI of Land Grabbing in the Amazon) in the state of Amazonas alone it is estimated that out of a total of 157 million hectares, about 55 million, approximately one third, were being acquired illegally. In the state of Pará at least 12 million hectares had already been acquired illegally by 2001. Furthermore, the Report states that "at the national level land grabbing has easily exceeded the total of 100 million hectares" (BRASIL, 2001, p. 569). Fonseca (2005, p. 63) goes further, stating that "it is estimated that there are 200 million hectares under suspicion of being occupied illegally (...) there are cases where land is expropriated and the alleged owner does not even know how much the expropriating authority issued on the possession - a typical case of land for purely speculative purposes." Ianni (1979), Oliveira (1997; 2007; 2011), Brasil (2001) and Fonseca (2005) are unanimous in affirming that the illegal occupation did not start in the dictatorial period of 1964 to 1985, but gained new strength and impetus as an policy legalized institutionally by the class fractions in power in this period. The alliance between land and capital demonstrated its force in the monstrous incorporation of public assets to carry out its private reproduction as an economic, social and political elite through the dominion of large portions of territory.

\section{FINAL CONSIDERATIONS}

With this article we aim to demonstrate the ideological foundations of the alliance between land and capital in the civil-military dictatorship, part of its territorial strategies and extensive legal and economic domination that produced indelible marks in maintaining political power under the auspices of the State apparatus.

From the dictatorship a class alliance was masterminded between capitalists and landowners who converged in an eminently oligarchic political project disguised as economic modernity and which is reproduced in contemporary times. The military coup carried out the transformation of the agenda of land reform as a battle flag and vindication of the distribution of land in a legal farce - in which the Land Statute, as problematized above, is an emblematic case - and a form of access to land for urban-industrial business and large capitalist companies and industries, conducting a new round of land concentration and the original accumulation of capital. Land grabbing is deliberately reset in the formation of Brazilian territory as a fundamental legacy that produces the alleged legality of capitalist private land ownership through a wide range of illegal expedients.

Thus the rentier path of Brazilian capitalism was consolidated into a form of capitalist development which reproduced the economic, social and political latifundium, revealing that the capital accumulation process remains robust. The alliance between land and capital crossed the ideological dimension and put into practice a wide range of territorial strategies as the means, condition and product of reproduction of the elites in power.

In our view, the formation of the Brazilian territory is caused by a specific sui generis: the formation of private landownership is based on the use of land grabbing at all times in Brazilian 
history, producing and also reproducing the class of large landowners and their political, social and economic power. The civil-military dictatorship allied the economic interests of landowners and the urban-industrial bourgeoisie, deepening relationships previously established on the political-ideological level and on the social structure of power and privilege.

The concentration of the Brazilian agrarian structure and its peremptory territorial expression, the latifundium, have shaped themselves into legal, social, economic and political mechanisms arising from a continuous reproduction of the original accumulation of capital. In other words, the permanence of (non-capitalist) production of capital is evident in Brazilian capitalism. The private appropriation of vacant and public lands and the ways of creating and circumventing laws, the territorial pacts and economic alliances between bourgeois social classes, the consolidation of political interests from the dominance (or consent to the dominance of the allied classes) of the State reveal that capitalism in Brazil presents a specific development path based on the centrality of the excessive appropriation of (super) income from the land leading to Brazilian style profiteering.

Denunciation of the arrangements for the widespread illegal appropriation of vacant and public lands in the dictatorial period culminated in the introduction of Article 51 to the Transitional Constitutional Provisions Act of the Federal Constitution of 1988. The legal text foresees the review process

by the National Congress, through a Joint Commission within three years from the date of the promulgation of the Constitution of all donations, sales and concessions of public lands with an area greater than three thousand hectares, held in the period of January 1, 1962 to December 31, 1987. (BRASIL, 1988, p. 50).

However, according to Oliveira (2007) and Figueira (2000) until now the National Congress has done nothing to arrange this review, incontestable proof of the legacy of land grabbing and one of the largest land concentrations on a global scale that the civil-military dictatorship, the state vector of the class alliance, contributed to relegate Brazilian territorial formation.

\section{ACKNOWLEDGEMENTS}

To the National Scientific and Technological Development Council (CNPq) for the PhD scholarship in Brazil and the Higher Education Personnel Improvement Coordination (CAPES) for granting a doctoral sandwich scholarship at the École des Hautes Études en Sciences Sociales - Paris, France.

\section{BIBLIOGRAPHIC REFERENCES}

BRASIL. Mensagem ao Congresso Nacional. Remetida pelo Presidente da Republica na abertura da sessão legislativa de 1964. Brasília - DF: Presidência da República. Casa Civil. Secretaria de Administração. Diretoria de Gestão de Pessoas. Coordenação Geral de Documentação e Informação. Coordenação de Biblioteca. BRASIL. Mensagem n. 33, de 26 de outubro de 1964. Encaminha ao Congresso Nacional o Projeto de Lei que dispõe sobre o Estatuto da Terra. Brasília - DF, 1964b.

BRASIL. Lei no 4.504, de 30 de novembro de 1964. Dispõe sobre o Estatuto da Terra. Brasília-DF, 1964c. BRASIL. Constituição (1946). Emenda Constitucional no 10, de 9 de novembro de 1964d.

BRASIL. Ato institucional n. 1. Diário Oficial de 9 de abril de 1964, pág. 3.193. Rep. no DO de 11 de abril de 1964, p. 3.257. Disponível em: <www.senado.gov.br>. Acesso em: 03 mar. 2005. [BRASIL, 1964e] BRASIL. A revolução e as reformas. Discurso proferido ao inaugurar a Escola Normal Rural Ildefonso Simões Lopes. Osório - Rio Grande do Sul, 22 mai. 1964.[BRASIL, 1964f]. 
BRASIL. Constituição (1967). Constituição do Brasil, de 24 de janeiro de 1967. Brasília - DF, 1967. BRASIL. Constituição (1988). Constituição da Republica Fed. do Brasil, de 5/10/1988. Brasília - DF, 1988 BRASIL. Min. de Pol. Fund. e da Agric.Familiar/INCRA. Livro Branco da Grilagem. Brasília - DF, 2000. BRASIL. Relatório da Comissão Parlamentar de Inquérito destinada à investigar a ocupação de terras públicas na região amazônica. Relator: Deputado Sérgio Carvalho. Brasília - DF, 2001.

BRUNO, R. A. L. O Estatuto da Terra. Estudos Sociedade e Agricultura, Seropédica, v. 4, pp. 5-31, 1995. CAMARGO, A. A. A questão agrária: crise de poder e reformas de base (1930-1964). In: GOMES, A. M. C. et al. História Geral da Civilização Brasileira. Rio de Janeiro: Bertrand Brasil, 2007, pp.147-272 DREIFUSS, R. 1964: A conquista do Estado (Ação política, poder e golpe de classe). Petrópolis: Vozes, 1981. CARVAlho filHO, J. J. Política Fundiária. São Paulo em Perspectiva, v.11/no 2, p. 26-34, 1997.

FIGUEIRA, R. R. A justiça do lobo: posseiros e padres do Araguaia. Petrópolis: Vozes, 1986.

FIGUEIRA, R. R. Por que trabalho escravo? Estudos Avançados. São Paulo, v. 14, n.38, p. 31-50, 2000.

FONSECA, A. Juros compensatórios ou juros de dano: discussão das súmulas 618, 416, 345 e 164 do STF (exposição de motivos para provocar o cancelamento das súmulas 618, 416, 345 e 164). Brasília, 2005. GARCIA JR, A. Reconversion des élites agraires. Études rurales, n. 131-132, 1993, p. 89-105.

KAWANO, K. Brèves remarques hétérodoxes sur l'histoire moderne du Japon. Annales. Économies, Sociétés, Civilisations. v. 17, n. 6, 1962. pp. 1137-1140.

IANNI, O. A luta pela terra. Petrópolis: Vozes, 1979.

LOUREIRO, V.; PINTO, J. A questão fundiária na Amazônia. Estudos Avançados, v. 19, p. 77-98, 2005.

MARÉS, C. F. A função social da terra. Porto Alegre: Sergio Antonio Fabris Editor, 2003.

MARTINS, J. S. Expropriação e violência (A questão política no campo). São Paulo: Hucitec, 1980.

MARTINS, J. S. Os camponeses e a política no Brasil. Petrópolis: Vozes, 1981.

MARTINS, J. S. O poder do atraso: ensaios de sociologia da história lenta. São Paulo: Hucitec, 1994.

OLIVEIRA, A. U. A fronteira amazônica mato-grossense: grilagem, corrupção e violência. 1997. 2v. Tese (Livre Docência) - Fac. de Filosofia, Letras e Ciências Humanas, Universidade de São Paulo, São Paulo, 1997.

OLIVEIRA, A. U. Modo capitalista de produção, agricultura e reforma agrária. São Paulo: FFLCH/ LABUR Edições, 2007.

OLIVEIRA, A. U. Grilagem de terras. Le Monde Diplomatique, São Paulo, p. 24-25, 01 mar. 2009.

OLIVEIRA, A. U. A geografia agrária e as transformações territoriais no campo brasileiro. In: CARLOS, A. F. A. (org). Novos caminhos da Geografia. São Paulo: Contexto, 2010.

OLIVEIRA, A. U. A questão da aquisição de terras por estrangeiros no Brasil - um retorno aos dossiês. AGRÁRIA, São Paulo, n. 12, p. 3-113, 2011.

PAULINO E.; ALMEIDA, R. Terra e território. São Paulo: Expressão Popular, 2010.

PEREIRA, H. Criar ilhas de sanidade: Os Estados Unidos e a Aliança para o Progresso no Brasil. 2005. Tese (Doutorado) - Faculdade de Ciências Sociais, Pontifícia Universidade Católica de São Paulo, PUC/SP, 2005. PINTO, L. F. O fim da Amazônia. Manaus: UEA Edições, 2014.

POST, C. Agrarian Class Structure and Economic Development in Colonial British North America: The place of the American Revolution in the origins of US Capitalism. Journal of Agrarian Change v. 9, n. 4, 2009. RIBEIRO, V. Fazendas e quartéis. Passagens, v. 02, p. 94-129, 2010.

RIBEIRO, A. Princípio da função social na legislação agrária brasileira. São Luís: UFMA, 2006.

RIBEIRO, R. A Aliança para o Progresso e as Relações Brasil-Estados Unidos. 2006. Tese (Doutorado) - Instituto de Filosofia e Ciências Humanas, Universidade Estadual de Campinas, Campinas. 2006.

SILVA, L. O. Terra, Direito e Poder. Boletim da ABA, Campinas, v. 27, p. 17-22, 1997.

SILVA, L. O. Desenvolvimentismo e intervencionismo militar. Idéias, v. 12/13, n.1, p. 11-40, 2006.

SILVA, J. G. Reforma agrária no Brasil. Rio de Janeiro, Zahar, 1971.

WOOD, E. M. L'origine du capitalisme: une etude approfondie. Montréal: Lux Éditeur: 2009. 